\title{
Anatomoclinical Varieties of Urethral Ectropion in Females: Cases of the Young Girl and the Elderly Woman
}

\author{
Fred Hodonou ${ }^{1 *}$, Josué Avakoudjo ${ }^{1}$ and Fouad Soumanou ${ }^{2}$ \\ ${ }^{1}$ Assistant Professor, Universitary Clinic of Urology in National Teaching Hospital HKM of Cotonou, Benin. \\ ${ }^{2}$ Urologist, Teaching Hospital or Suru Lere, Cotonou, Benin
}

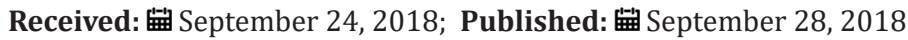

*Corresponding author: Hodonou Fred, Urologist, Assistant Professor, Universitary Clinic of Urology in National Teaching Hospital HKM of Cotonou Benin

\begin{abstract}
Urethral ectropion is most common in young girls than elderly woman. The objective in this study was to show anatomopathologic and clinic types of urethral ectropion. We were reported two cases in young girls and one case in 67 years old woman. The clinical symptoms were same. But in the case of old woman we founded right lymph nodes. Biopsy had done in two cases on three. In one of both girls we were discovered after anatomopathology, a vessels thrombosis but in a year-old-woman it was urethral adenocarcinoma. Management of urethral ectropion depends of age (young girl or elderly woman) and staging of tumor if it was urethral carcinoma.
\end{abstract}

Keywords: Ectropion; Urethral; Biopsy; Adenocarcinoma.

\section{Introduction}

Urethral ectropion is a mucosal prolapse of the urethra. Mucosal prolapse is the circumferential eversion of the distal urethral epithelium in young girls or after menopause [1]. In black females, it is more common in girls than in elder women. Its etiology may be known as it may not. The interest in an anatomo-clinical study comparing the cases of young girls and elderly women that has not yet been carried out motivated this case study.

\section{Case Report}

\section{Case 1}

It was a 10-year-old girl admitted in consultation for a dysuria that had been for evolving for 2 months. In her history, there was a notion of falling astride. Her general condition was satisfactory. The urogenital examination noted particularly mucosal prolapse of the urethra painful to palpation and bleeding easily on contact. We conclude with a urethral ectropion. The patient was put on anti-inflammatory suppository. A sample taken for an anatomopathological analysis reveals a venous thrombosis. She was examined again after 2 weeks and it was observed that the treatment registered no regression of the urethral ectropion. A venous thrombosis surgery was then decided on, but we were confronted with a refusal of her parents.

\section{Case 2}

This was a girl of 7 years received in consultation for a dysuria that had been evolving for 2 weeks. She had no history of medical surgery. Her general condition was satisfactory. The urogenital examination noted mucosal prolapse of the urethra painful on palpation and bleeding on contact. We diagnosed urethral ectropion. She was put under a treatment of anti-inflammatory suppository for 2 weeks. We noted a significant regression of urethral ectropion and suggested she continue the treatment for another 2 weeks.

\section{Case 3}

It was a 67-year-old patient admitted for dysuria, urinary burning and hematuria. She had no medical-surgical history. Her general condition was satisfactory. On urogenital examination, right pelvic and iliac lymph nodes have been found. We observed, at the separation of the large and small lips, a urethral ectropion bleeding on contact and painful with whitish discharge. A cytobacteriological examination was requested which revealed staphylococcus aureus sensitive to betalactamins and fluoroquinolons, with which she was then treated. A biopsy of the urethral prolapse was made for anatomopathological analysis. The result was a urethral adenocarcinoma. Uroscanner objectified the presence of bilateral 
iliopelvic lymph nodes of size $5 \mathrm{~mm}$ to $15 \mathrm{~mm}$ with its necrotic center on the right; an invasion of the right lateral horn of the bladder; uterus, vagina and the colon were normal (not invaded). She was at the T3N2M0 stage of the disease. Radiation therapy was recommended and was performed.

\section{Discussion}

Mucosal prolapse is a rare pathology that was described in 1732 by Solingen [2]. Its incidence is underestimated in tropical environment due to his ignorance [3]. Three facts are to be mentioned which are found in most series of mucosal prolapse of the urethra in children [3]:

a) The usual occurrence of urethral prolapse at the extreme ages of life (at the age of the child and at menopause)

b) The age of occurrence of cases, which frequency peaks in children are between 3 and 10 years [2,4,5]

c) The clear predominance of the occurrence of this lesion in the black girl who are mainly touched [our case] [3,6]. However, the white race is not spared. Studies in Russia, Poland and Korea confirm this fact [7-10].

Risk factors for mucosal prolapse are known but it also can be idiopathic. But in this study one of the patients had a fall astride, after which she suffered from the mucous prolapse of the urethra. According to Fernandes et al. [11], chronic cough, constipation, trauma, urinary and vaginal infections, malnutrition, excessive urethral mucosa and physical exertion would be predisposing factors. The mucosal prolapsed of the child's urethra have been often reported while rare articles have discussed mucosal prolapse in elderly women. Thus, when it occurs in an elderly or menopausal woman, biopsy should be made to elucidate the underlying pathology. It may hide a urethral tumor. This is the case in our study and that of other authors where after a biopsy of a urethral ectropion was carried out, a urethral tumor was found $[12,13]$. The last two studies and this one, point to the advanced age of the patients. Primary carcinoma of the urethra is rare and represents less than $1 \%$ of urogenital cancers [14,15]. Its incidence is 3 to 4 times more common in women than in men and increases with age with a peak at 75 years, especially among black Americans $[16,17]$. The risk factors for urethral cancer in women are: urethral diverticulum, chronic irritations and infections with the papilloma virus and recurrent urinary tract infections [18,19]. In the anatomical varieties of the patients we find a venous thrombosis with one of the girls and a urethral adenocarcinoma in the elderly woman. In Ludovic's study [3] on the histological results of urethral prolapse in children, 9 out of 12 cases presented various histological aspects: squamous hyperplasia 5 cases; polymorph infiltrate and vein thromboses (2 cases each); hyperplastic polyp, ectropion mucosa and glandular urethritis with focal eosinophilia ( 1 case each). The other studies $[12,13]$ reported respectively in the elderly woman: one case of squamous cell carcinoma and one case of squamous metaplasia.

\section{Conclusion}

Urethral ectropion or mucosal prolapse of the urethra is a benign condition in the girl child. But in the elderly woman, this can be a malignant condition. A biopsy of urethral prolapse in the elderly woman must be made. Thus the treatment of ectropion is in function of the age of the patient (girl or elderly woman) and of the tumor stage in case of a urethral cancer. Management may be medicated and/or surgical and/or by radio chemotherapy.

\section{References}

1. Essiet A, Ikpi E, Essiet GA (2007) Uretral prolapse: a case report and commentary on management. Afr J Urol 13: 50-53.

2. Akpo EC, Aguessy Ahyi B, Padonou M (1983) A propos de 13 observations. J urol 89: 351-353.

3. Ludovic Falandry [1996] Le prolapsus urétral de l'enfant chez la fille de race noire. A propos de 12 observations. Prog Urol 6: 392-397.

4. Akani CI, Pepple DK, Ugboma HA (2005) Urethal prolapse : a retrospective analysed of hospitalized cases in Port Harcount. Niger J Med 4: 396-399.

5. Shurtleff BT, Barone JG (2002) Urethral prolapse: four quadrant excisional technique. J Pediatr Adolesc Gynecol 15: 209-211.

6. Sanda GO, Soumana A, Oumarou H (2012) Le prolapsus muqueux de l'urètre chez la fille : A propos de 22 cas colligés en dix ans et une revue de littérature. Afr JUrol 18: 93-96.

7. Rudin JE, Geldt VG, Alekseev EB (1997) Prolapse of urethral mucosa in white female children: experience with 58 cases J Pediatr Surg 32: 423425 .

8. Doletskil Sla, Gel'dt VG, Rudin luE (1990) Prolapse of the urethral mucosa in girls. Khirurgiira 8: 52-57.

9. Zymkiewicz C, Smolinska Bellen E (1976) Urethral mucosa prolapse in little girls. Pediatr Pol 51: 1213-1216.

10. Valerie E, Gilchrist BF, Frisher J (1999) Diagnosis and treatment of urethral prolapse in children. Urol 54: 1082-1084.

11. Fernandes ET, Dekermarcher S, Sabadin MA (1993) Urethral prolapse in children. Urol 41: 240-242.

12. Mohammed Alae Touzani, Othmane Yddoussalah (2017) Urethral ectropion may hide a carcinoma. Pan African Medical Journal 27:249.

13. Amine Slaoui, Souhail Regragui, Tarik Karmouni, Khalid El khader (2017) Female urethral ectropion. Glob J Reprod Med 1:1.

14. Dalbagni G, Zhang ZF, Lacombe L (1998) Female urethral carcinoma: an analysis of treatment outcome and a plea for a standardized management strategy. Br J Urol 82(6): 835-841.

15. Dalbagni G, Zhang ZF, Lacombe L (1999) Male urethral carcinoma: analysis of treatment outcome. Urology 53(6): 1126-1132.

16. Traboulsi SL, Witjes JA, Kassouf W (2016) Contemporary management of primary Distal urethral Cancer. Urol Clin N Am 43(4): 493-503.

17. Swartz MA, Porter MP, Lin DW (2006) Incidence of primary urethral carcinoma in the United States. Urology 68: 1164-1168.

18. Ahmed K, Dasgupta R, Vats A (2010) Urethral diverticular carcinoma: an overview of current trends in diagnosis and management. Int Urol Nephrol 42(2): 331-341.

19. Libby B, Chao D, Schneider BF (2010) Non-surgical treatment of primary female urethral cancer. Rare Tumors 2(3): e55. 
(C) (i) This work is licensed under Creative

To Submit Your Article Click Here:

Submit Article

DOI: $10.32474 / J U N S .2018 .01 .000113$

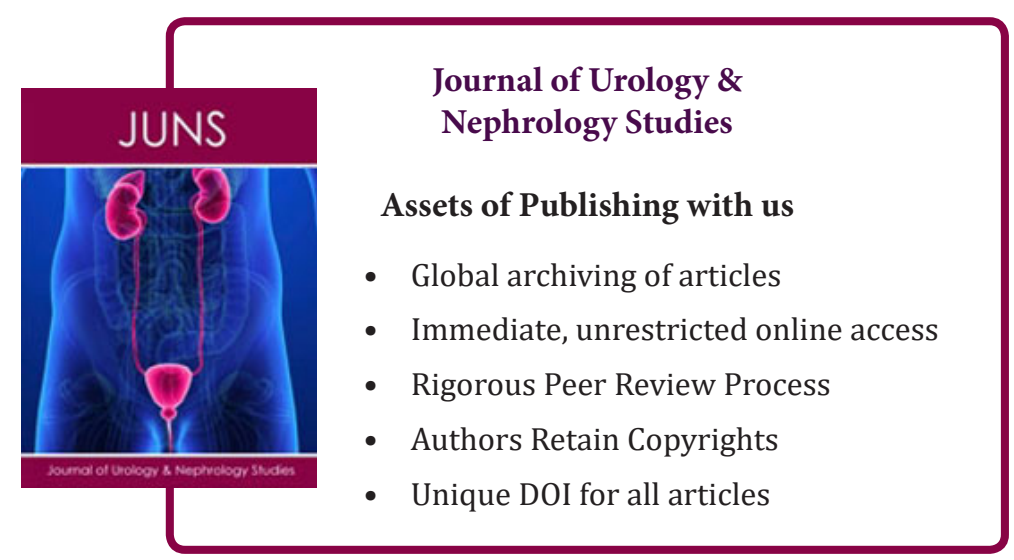

